\title{
Biomass in the Deregulated Marketplace Current Issues for Biomass Power
}

\author{
December 1998
}

Prepared for:

United States Department of Energy's Biomass Power Program and the National Renewable Energy Laboratory (NREL)

Task Order No. 2

Task Ordering Agreement No. KAW-5-15061-00

Prepared by:

Antares Group Inc.

4351 Garden City Drive, Suite 301

Landover, Maryland 20785

Disclaimer: The content of this document does not represent the opinions or policies of the U.S. Department of Energy or Antares Group, Incorporated. In an effort to provide timely information, secondary data sources are used and therefore, the accuracy of the content of the summaries is not guaranteed. 


\section{TABLE OF CONTENTS}

$1.0 \quad$ Biomass in the Deregulated Marketplace $\ldots \ldots \ldots \ldots \ldots \ldots \ldots \ldots \ldots \ldots \ldots \ldots \ldots \ldots \ldots$

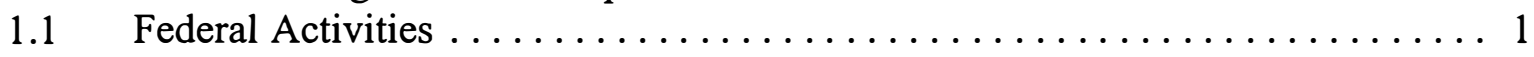

$1.2 \quad$ State Activities . . . . . . . . . . . . . . . . . . . . . . . . . 2

1.3 Monthly Highlight Topic - Energy Policy Act Section $45 \ldots \ldots \ldots \ldots \ldots 2$

$1.4 \quad$ Current Challenges ..................................... 7

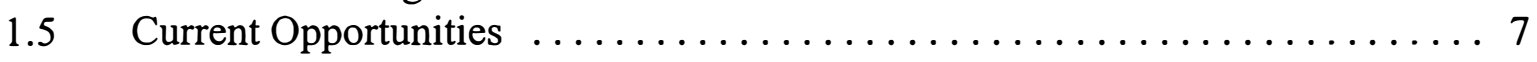




\subsection{Biomass in the Deregulated Marketplace}

This issue brief provides readers with a monthly review and analysis of electric utility deregulation as it impacts biomass power production and distribution. Each issue covers information generated roughly from the $15^{\text {th }}$ of the previous month to the $15^{\text {th }}$ of the current month. The topical areas to be routinely covered will include Federal activities, State activities, Current challenges, and Current opportunities. Additionally, a monthly highlighted topic will provide more in-depth analysis of a current issue impacting biomass power. To allow easy access and facilitate wider distribution, "Biomass in the Deregulated Marketplace" is posted monthly on the Internet at http://www.antares.org.

\subsection{Federal Activities}

The DOE Annual Energy Outlook 1999 (AEO99) was published in mid December. The AEO99 presents mid-term forcasts of energy supply, demand, and prices through 2020 based on projection results from EIA's National Energy Modeling System (NEMS). The following points were made in the EIA report:

- Biomass leads projected growth in generation from renewables growing to 91 billion kilowatt hours production in 2020 and approaching 2 percent of U.S. electricity generation. According to EIA, "The increases reflect expected improvements in generation technologies, new energy crops, and growth of industries using wood byproducts for cogeneration."

- A renewable portfolio standard would benefit biomass and wind plants most. There are significant low-cost supplies of biomass residues available and not currently used for electricity production. These materials can be used as a secondary fuel in existing coal-fired power plants. The EIA assumes up to 5 percent of the heat input of coal units can be replaced with biomass residues if it is economical.

Several legislative items were introduced in the $105^{\text {th }}$ Congress but were not acted upon. They may reappear in the $106^{\text {th }}$ Congress. They are briefly discussed below.

-S. 2453 was introduced to extend the section 45 credit to poultry waste and to extend the qualifying date to 2004 .

-H.R. 4407 was introduced to extend the section 45 credit to various biomass residues as long as they were combusted in a power plant using over 75 percent of its heat input from biomass.

-S. 2617 was introduced to provide credit for early action agreements for greenhouse gas reduction before 2008 . 


\section{$1.2 \quad$ State Activities}

Green Mountain Energy introduced three "clean" energy products for Pennsylvania markets. Power from the Eco Smart product is a mix of 99 percent natural gas or large hydroelectric power and 1 percent renewable. The Enviro Blend is half natural gas or large hydroelectric and half renewable, while the Nature's Choice option is 100 percent renewable, 5 percent of which are new. (EIN, Renewable Energy Today, 11/17/98).

The Los Angeles Department of Water and Power will require all commercial and industrial customers to purchase between 500 and 1,000 kilowatt hours of green power each month beginning in the first quarter of 1999 . Biomass, solar, and wind all qualify as green. Residential customers will also have an option to buy green power. (EIN, Renewable Energy Today, $12 / 4 / 98)$.

\subsection{Monthly Highlight Topic - Energy Policy Act Section 45}

The ANTARES Group performed a cost-benefit analysis for each of four potential changes of the Section 45 tax credit language. The model developed for this effort can easily be modified to estimate results for alternative scenarios. Results are summarized in Exhibits 1 and 2. Exhibit 1 presents results summarized over the entire analysis period (1999 - 2028), and Exhibit 2 presents cumulative results for each case over the first five years. Annual results, cumulative results, net present values, and environmental benefits for each case are presented in the tables following Exhibits 1 and 2. Key technical and economic inputs and assumptions are shown in the final two tables.

\section{Potential Changes:}

If no changes are made to the existing section 45 tax credit definition, no costs will be incurred by the U.S. treasury because no biomass facilities will qualify by the expiration date: Costs and benefits will both be zero. This scenario is shown as Case "A" in the following tables. The four new scenarios considered were:

B. Date Extension Only--Extension of the expiration date of the existing Section 45 tax credit by 10 years. The expiration date for eligibility of the credit will change from June 30, 1999 to June 30, 2009.

The policy driver for this scenario would be to allow the existing, previously unused (for biomass projects) Section 45 tax credit to be used in future years. This will provide an additional economic incentive for several first-generation biomass power projects that will each utilize "closed-loop" energy crop feedstocks.

C. Date Extension and Inclusion of Cofiring--Extension of the expiration date for eligibility of the existing Section 45 tax credit from June 30, 1999 to June 30, 2009. Also change construction date of a Qualifying Facility from 1993 to 1945. Maintain existing "closed-loop" definition. 
The policy driver for this scenario would be the desire to encourage more "closed-loop" biomass power projects by allowing biomass cofiring projects to take advantage of the tax credit when combusting energy crops.

D. Date Extension and Inclusion of Cofiring and Biomass Residues--Extension of the expiration date for eligibility of the existing Section 45 tax credit from June 30, 1999 to June 30, 2009. Change construction date of a Qualifying Facility from 1993 to 1945. Change existing "closed-loop" definition to include timber stand improvement (TSI) and biomass residues (qualifying biomass residue must be $100 \%$ wood, agricultural residue, animal manure or any combination thereof). Energy crops, TSI, residues, and animal manure would qualify for a $1.5 \mathrm{k} / \mathrm{kWh}$ credit. Average heat rate of the power generation facility must be less than or equal to $10,500 \mathrm{Btu} / \mathrm{kWh}$. For cofiring, the credit will be applied only to that fraction of the power that is generated from biomass (based on the fraction of the plant's total annual heat input that is derived from biomass).

The policy driver for this scenario would be to encourage development of energy crops and the use of biomass residues for significant growth of biomass technologies and the associated environmental and economic development activities. By using a minimum heat rate requirement of $10,500 \mathrm{Btu} / \mathrm{kWh}$, this policy would exclude existing biomass plants and high heat rate direct-fired technologies.

E. Date Extension and Inclusion of Cofiring, Biomass Residues, and Existing Biopower Facilities Outside the Pulp and Paper Industry--Extension of the expiration date for eligibility of the existing Section 45 tax credit from June 30, 1999 to June 30, 2009. Change construction date of a Qualifying Facility from 1993 to 1945. Change existing "closed-loop" definition to include timber stand improvement and biomass residues (qualifying biomass residue must be $100 \%$ wood, agricultural residue, animal manure or any combination thereof). Energy crops, TSI, residues and animal manure would qualify for a $1.5 \phi / \mathrm{kWh}$ credit. For cofiring, the credit will be applied only to that fraction of the power that is generated from biomass (based on the fraction of the plant's total annual heat input that is derived from biomass). The pulp and paper industry is excluded from receiving the credit.

The policy driver for this scenario would be to encourage development of energy crops and the use of biomass residues for significant growth of biomass technologies and the associated environmental and economic development activities. This option would also help existing biopower facilities (outside the pulp and paper industry) to continue operating by allowing them to qualify for the $1.5 \mathrm{c} / \mathrm{kWh}$ tax credit.

\section{F. Date Extension and Inclusion of Cofiring, Biomass Residues, and All Existing}

Biopower Facilities--Extension of the expiration date for eligibility of the existing Section 45 tax credit from June 30, 1999 to June 30, 2009. Change construction date of a Qualifying Facility from 1993 to 1945 . Change existing "closed-loop" definition to include timber stand improvement and biomass residues (qualifying biomass residue must 
be $100 \%$ wood, agricultural residue, animal manure or any combination thereof). Energy crops, TSI, residues and animal manure would qualify for a $1.5 \mathrm{~d} / \mathrm{kWh}$ credit. For cofiring, the credit will be applied only to that fraction of the power that is generated from biomass (based on the fraction of the plant's total annual heat input that is derived from biomass).

The policy driver for this scenario would be to encourage development of energy crops and the use of biomass residues for significant growth of biomass technologies and the associated environmental and economic development activities. This option would also help existing biopower facilities to continue operating by allowing them to qualify for the $1.5 \phi / \mathrm{kWh}$ tax credit.

For each scenario, estimates for the amount of biomass power generation that would qualify for the tax credit were made. The projected biopower growth is intended to be high but technically achievable, reflecting a high-cost scenario from the U.S. treasury. Costs to the U.S. treasury were calculated on an annual basis. Benefits to the treasury were estimated based on income and payroll taxes received by the treasury from direct, indirect, and induced job creation. ANTARES assumed a net job creation rate of one job/MW for new biomass facilities, based on previous experience and analyses. The net cost to the U.S. treasury was calculated as the difference between the tax credit value and the new taxes received by the treasury. Environmental benefits (Carbon, $\mathrm{SO}_{x}$, and $\mathrm{NO}_{x}$ emission reductions) were also estimated on an annual basis.

Environmental and new tax revenue benefits produced by biomass facilities after their 10-year tax credit period expires were included. Cofiring facilities were assumed to have a life of 15 years (environmental and tax revenue benefits last for 15 years, but the tax credit only lasts for 10 years). Gasification facilities were assumed to have a life of 20 years. For each scenario, the net present value (10 percent discount rate) of the costs were calculated over the 30-year analysis period based.

Metrics to consider when comparing the scenarios are: 1) net present value of the net costs to the U.S. treasury, 2) the total estimated amount of qualifying biomass installed over the life of the credit, and 3) the discounted net cost to the U.S. treasury per tonne of carbon emissions reduced. A summary of the results for the scenarios considered is shown below.

The second scenario, Date Extension and Inclusion of Cofiring, would be a simple change in Section 45 language but would make a significant impact in terms of the number of biomass facilities that would be able to take advantage of the credit. 
Exhibit 1

Summary of Results Over the 30-year Analysis Period, Section 45 Tax Credits

\begin{tabular}{|c|c|c|c|c|c|c|c|c|c|c|}
\hline No. & Scenario Description & $\begin{array}{c}\text { Cumulative } \\
\text { Cost to U.S. } \\
\text { Treasury, } \\
\text { (Undiscounted) } \\
\text { million S } \\
\end{array}$ & \begin{tabular}{|} 
Average Annual \\
Cost to U.S. \\
Treasury, \\
(Undiscounted, \\
1st 10-yrs) \\
million \$/yr \\
\end{tabular} & $\begin{array}{c}\text { Net Present } \\
\text { Value of Cost } \\
\text { to U.S. } \\
\text { Treasury, } \\
\text { million \$ } \\
\end{array}$ & $\begin{array}{l}\text { Net Present } \\
\text { Value of } \mathrm{Net} \\
\text { Cost to U.S. } \\
\text { Treasury, } \\
\text { million } \$\end{array}$ & $\begin{array}{l}\text { Qualifying } \\
\text { Biomass } \\
\text { Power } \\
\text { (MW) }\end{array}$ & $\begin{array}{l}\text { Total } \\
\text { Reduced } \\
\text { Carbon } \\
\text { Emissions } \\
\text { (tonnes) }\end{array}$ & $\begin{array}{l}\text { Total } \\
\text { Reduced } \\
\text { Sulfur } \\
\text { Dioxide } \\
\text { Emissions } \\
\text { (tonnes) }\end{array}$ & $\begin{array}{c}\text { Total } \\
\text { Reduced } \\
\text { Nitrogen } \\
\text { Oxide(s) } \\
\text { Emissions } \\
\text { (tonnes) }\end{array}$ & \begin{tabular}{|} 
Discounted \\
Net S per \\
Metric Ton of \\
Carbon \\
Reduced
\end{tabular} \\
\hline A & Baseline--No change & 0.0 & 0.0 & 0.0 & 0.0 & 0 & 0 & 0 & 0 & N/A \\
\hline B & Date Extension Only & 52.8 & 4.2 & 26.8 & 18.3 & 60 & $1,179,574$ & 42,923 & 3,095 & 15.5 \\
\hline C & $\begin{array}{l}\text { Date Extension and Inclusion of } \\
\text { Cofiring, energy crops only }\end{array}$ & $1,127.1$ & 25.2 & 338.7 & 241.4 & 1,280 & $29,358,818$ & $1,068,334$ & 118,454 & 8.2 \\
\hline D & $\begin{array}{l}\text { Date Extension and Inclusion of } \\
\text { Cofiring and Biomass Residues at } 1.5 \\
\mathrm{c} / \mathrm{kWh} \mathrm{w} / \mathrm{a} \text { minimum heat rate } \\
\text { requirement of } 10.500 \mathrm{Btu} / \mathrm{kWh} .\end{array}$ & $5,149.0$ & 184.7 & $1,785.8$ & $1,259.7$ & 5,849 & $129,329,267$ & $4,706,146$ & 481,166 & 9.7 \\
\hline $\mathrm{E}$ & $\begin{array}{l}\text { Date Extension and Inclusion of } \\
\text { Cofiring and Biomass Residues at } 1.5 \\
\mathrm{c} / \mathrm{kWh} \mathrm{w} / \mathrm{no} \text { minimum heat rate } \\
\text { requirement (no pulp \& paper } \\
\text { biopower qualifies) }\end{array}$ & $6,821.7$ & 352.0 & $2,813.6$ & $2,287.6$ & $7,749^{\text {note } 2}$ & $129,329,267$ & $4,706,146$ & 481,166 & 17.7 \\
\hline $\mathrm{F}$ & $\begin{array}{l}\text { Date Extension and Inclusion of } \\
\text { Cofiring and Biomass Residues at } 1.5 \\
\mathrm{c} / \mathrm{kWh} \mathrm{w} / \text { no minimum heat rate } \\
\text { requirement (all existing biopower } \\
\text { qualifies) }\end{array}$ & $11,575.8$ & 827.4 & $5,734.8$ & $5,208.7$ & $13,149^{\text {nolte } 3}$ & $129,329,267$ & $4,706,146$ & 481,166 & 40.3 \\
\hline
\end{tabular}

\section{NOTES:}

1) Tabulated values are based on costs and benefits over the lives of the qualified biomass facilities.

2) This total includes the existing $1.9 \mathrm{GW}$ of biomass capacity. New capacity additions are estimated at $5,849 \mathrm{MW}$.

3) This total includes the existing $7.3 \mathrm{GW}$ of biomass capacity. New capacity additions are estimated at 5,849 MW. 
Exhibit 2

Summary of Section 45 Biomass Tax Credit Scenarios

\begin{tabular}{|c|c|c|c|c|}
\hline \multirow[b]{2}{*}{ No. } & \multirow[b]{2}{*}{ Proposed Change } & \multirow[b]{2}{*}{ Policy Driver } & \multicolumn{2}{|c|}{$\begin{array}{c}\text { Cumulative Effect } \\
\text { After 5-years }\end{array}$} \\
\hline & & & $\begin{array}{l}\text { New } \\
\text { Qualifying } \\
\text { Biopower } \\
\text { MW }\end{array}$ & $\begin{array}{l}\text { Cost to } \\
\text { Treasury } \\
\text { (million \$) }\end{array}$ \\
\hline A & $\begin{array}{l}\text { Baseline Case--No change to the existing Section } 45 \text { tax credit } \\
\text { definition. Credit expires on June } 30,1999 .\end{array}$ & $\begin{array}{l}\text { The original policy driver was to enhance the viability of first-generation } \\
\text { biomass power facilities based on "closed-loop" energy crop feedstocks. } \\
\text { This credit will expire on June 30,1999 without ever having been used } \\
\text { (for biomass). }\end{array}$ & 0 & 0 \\
\hline $\mathrm{B}$ & $\begin{array}{l}\text { Date Extension Only--Extension of the expiration date of the } \\
\text { existing Section } 45 \text { tax credit by } 10 \text { years. The expiration date } \\
\text { for eligibility of the credit will change from June } 30,1999 \text { to } \\
\text { June } 30,2009 \text {. }\end{array}$ & $\begin{array}{l}\text { To allow the existing, previously unused (for biomass projects) Section } \\
45 \text { tax credit to be used in future years. This will provide an additional } \\
\text { economic incentive for several first-generation biomass power projects } \\
\text { that will each utilize "closed-loop" energy crop feedstocks. }\end{array}$ & 60 & 16 \\
\hline $\mathrm{C}$ & $\begin{array}{l}\text { Date Extension and Inclusion of Cofiring--Extension of the } \\
\text { expiration date for eligibility of the existing Section } 45 \text { tax } \\
\text { credit from June } 30,1999 \text { to June } 30,2009 \text {. Also change } \\
\text { construction date of a Qualifying Facility from } 1993 \text { to } 1945 . \\
\text { Maintain existing "closed-loop" definition. (SEE NOTE 1) }\end{array}$ & $\begin{array}{l}\text { To encourage "closed-loop" biomass power projects (including } \\
\text { cofiring), using the tax credit to pay for only energy crops. This will also } \\
\text { create significant new income opportunities in rural areas for those } \\
\text { involved in farming, processing, and hauling the energy crops. }\end{array}$ & 100 & 26 \\
\hline $\mathrm{D}$ & $\begin{array}{l}\text { Date Extension and Inclusion of Cofiring and Biomass } \\
\text { Residues at a } 1.5 \phi / \mathrm{kWh} \text { credit. Heat rate must be less than or } \\
\text { equal to } 10,500 \mathrm{Btu} / \mathrm{kWh} \text {. (SEE NOTES } 1 \& 2 \text { ) }\end{array}$ & $\begin{array}{l}\text { To encourage development of energy crops and the efficient utilization } \\
\text { of biomass residues for significant growth of biomass technologies and } \\
\text { the associated environmental and economic development benefits. }\end{array}$ & 1,504 & 350 \\
\hline $\mathrm{E}$ & $\begin{array}{l}\text { All existing and new biomass facilities (excluding those in the } \\
\text { pulp and paper industry), and cofiring installations. }\end{array}$ & All feedstocks, but no clear cuts. & 3,400 & 1,200 \\
\hline $\mathrm{F}$ & $\begin{array}{l}\text { All existing and new biomass facilities (including those in the } \\
\text { pulp and paper industry), and cofiring installations. }\end{array}$ & All feedstocks, but no clear cuts. & 8,800 & 3,600 \\
\hline
\end{tabular}

NOTE: 1) For cofiring, the credit will be applied only to that fraction of the power that's generated from biomass (based on the fraction of the plant's total annual heat input that is derived from biomass).

2) Qualifying biomass residues would include wood residues, ag. residues, and animal manure or any combination thereof.

3) In this table, "New Qualifying Biopower" means biopower facilities that would qualify for the tax credit under the scenario stated. It does not necessarily mean that the facility is a new biopower facility. For example, cases "E" and "F" allow existing biopower facilities to qualify for the credit. 


\subsection{Current Challenges}

USA Biomass Corporation announced it is evaluating a decision to focus efforts on biomass operations and discontinuing certain other operations such as real estate land planning. Currently the company has an agreement to transport green wastes collected by Waste Management away from the state's landfills. The company, traded over the counter, expects to report a net loss for the year ended August 3 exceeding $\$ 7$ million due largely to a one-time write-down of certain real estate assets. (EIN, Renewable Energy Today, 12/8/98).

The Sustainable Energy Coalition (SEC), are urging that the U.S. Government back up its signing of the Kyoto Protocol by moving money from the DOE FY 2000 research and development budget into activities aimed at clean energy technology. The group advocates an increase of $\$ 527$ million and $\$ 900$ million to the renewable energy and energy efficiency funding accounts respectively. (EIN, Renewable Energy Today, 11/25/98).

A renewable energy potential of about 1,350 megawatts exists in India according to government estimates. Current Indian forestry laws however, present obstacles for Shell International's desire to use its forestry resource for biomass electricity generation. Shell owns 210,000 hectares of land suitable for biomass in India. (EIN, Renewable Energy Today, 11/19/98).

\subsection{Current Opportunities}

According to the Association of German Electrical Power (VDEW) the amount of electricity generated from alternative renewable energy sources in Germany grew 30 percent from 1996, to a 1997 total of 5 billion kilowatt-hours. Biomass based fuels generated 600 million $\mathrm{kWh}$ of electricity, and increase of 100 million kWh from 1996. (EIN, Renewable Energy Today, 12/15/98).

Power Content Labels have been created by the California Energy Commission (CEC) to explain to state electricity customers how their power is produced. The label describes the various sources of electricity and contains information on the resource mix of specific products within the California Power Mix. The label will allow different power providers to distinguish themselves in the newly deregulated California market by offering green power to customers. More information on the Power Content label is available at http://www.energy.ca.gov/consumer. (EIN, Renewable Energy Today, 12/14/98).

Shell International Renewable Limited and the Ghana ministry of mines and energy are holding meetings on the development of electricity from sawdust and other timber waste resources. The program would begin in 1999 involving grid connected power. The company is also investigating systems for rural communities at least 20 kilometers away from the national power grid. ( Solar Letter, 12/18/98).

TransPacific Environmental, a subsidiary of USA Biomass has been hired by the Los Angeles County Sanitation District to recover shredded green waste from its Puente Hills Landfill. The tree year $\$ 500 \mathrm{k}$ annual contract calls for removal of 100 tons per day, six days per week, of shredded grass, leaf and tree trimmings. The company recycles and processes green waste 
biomass with the end products targeted to the landscape, fertilizer soil amendment, co-generation and other manufacturing industries. (EIN, Renewable Energy Today, 12/2/98).

Resource Data International (RDI) reports that deregulation will drive a trend that could enable green electricity to capture half of the $\$ 75$ billion in annual residential electricity sales by 2003 . The report maintains tant deregulation will force utilities to adopt environmentally friendly strategies to compete for customers. The report says that during the next 10 years, market growth will drive a 40 percent increase in the construction of renewable energy plants across the U.S. and a 60 percent jump in the Western U.S. (EIN, Renewable Energy Today, 11/30/98). 